\title{
An update on molecular genetics of gastrointestinal stromal tumours
}

\author{
L Tornillo, L M Terracciano
}

J Clin Pathol 2006;59:557-563. doi: 10.1136/icp.2005.031112

Gastrointestinal stromal tumours (GISTs) are the most common primary mesenchymal tumours of the gastrointestinal tract. Most of them show activating mutations of the genes coding for KIT or platelet-derived growth factor receptor $\alpha$ (PDGFR $\alpha$ ), two receptor tyrosine kinases (RTKs). The RTK inhibitor Imatinib (Gleevec ${ }^{\circledR}$, Novartis, Switzerland), induces regression of the tumour. The level of response to treatment, together with other clinicopathological parameters is related to the type and site of the activating mutation, thus suggesting that these tumours should be classified according to the molecular context. This is confirmed also by the phenomenon of the resistance to treatment, which arises because of different mechanisms (second mutation, amplification, activation of other RTKs) and can be fought only by specific RTK inhibitors, that are at present under development. RTK activation involves an homogeneous transduction pathway whose components (MAPK, AKT, PI3K, mTOR and RAS) are possible targets of new molecular treatment. A new paradigm of classification integrating the classic pathological criteria with the molecular changes will permit personalised prognosis and treatment.

See end of article for authors' affiliations ......................

Correspondence to: Dr Luigi Tornillo, Institute of Pathology, University of Basel, Schönbeinstrasse 40, CH-4003 Basel, Switzerland; tornillol@ uhbs.ch

Accepted for publication 17 January 2006

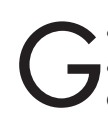
astrointestinal stromal tumours (GIST), although relatively rare, are the most common primary mesenchymal tumours of the gastrointestinal tract, with an incidence of nearly 20/1 000 000/year..$^{1-5}$ Their biological behaviour is difficult to predict, ranging from benign to malignant. The most reliable prognostic factors are size and mitotic index. On the basis of these factors (and to some extent on anatomical location), two risk classifications are proposed (tables 1 and 2). ${ }^{56}$

Stromal tumours of the gastrointestinal tract were regarded as smooth-muscle tumours (leiomyoma, leiomyoblastoma) until electron microscopy and immunohistochemistry analysis showed that only a small fraction of these tumours showed smooth-muscle differentiation. Therefore, in 1983 Mazur and Clark ${ }^{9}$ proposed the non-committal designation, stromal tumour, which now encompasses tumours with schwannian or neuronal differentiation (gastrointestinal autonomic nerve tumours, ${ }^{10}$ ). We now know that GISTs may have either a well-developed or an incomplete myoid, neural, autonomic nerve or mixed phenotype, or may remain undifferentiated. ${ }^{511}$ In the late 1990s, it was shown that GISTs share morphological, immunophenotypical and genetic characteristics with the interstitial cells of Cajal (ICCs), the pacemaker cells of the gut. ${ }^{212}{ }^{13}$ They have immunophenotypical and ultrastructural features of both smooth muscle and neuronal differentiation, and regulate peristalsis. Most GISTs express the tyrosin kinase KIT oncopro$\operatorname{tein}^{214}$ that is also the immunohistochemical marker of ICC. The expression of KIT is so strong and specific that it was claimed to be required for the diagnosis, ${ }^{3-5} 1516$ whereas it is now clear that a small, but significant fraction of GISTs (5-10\%) are indeed KIT negative. ${ }^{17-20}$

KIT is normally expressed in several cell types other than ICC. ${ }^{21}{ }^{22}$ In particular, KIT expression has a crucial role in embryogenesis, encouraging differentiation of primitive mesenchymal progenitor cells towards ICC and is essential to the formation of a functional ICC network. ${ }^{12}$ It belongs to the type III receptor tyrosine kinase (RTK) subfamily, whose members include platelet-derived growth factor receptors $\alpha$ and $\beta$ (PDGFR $\alpha$ and PDGFR $\beta$ ). All RTKIII contain five immunoglobulin-like domains in their extracellular ligand-binding region followed by a single transmembrane domain and a cytoplasmic tyrosine kinase domain interrupted by a large kinase insert. The ligand of KIT is known as stem cell factor ${ }^{22}$ As in other RTK, stem cell factor induces dimerisation of KIT followed by transautophosphorylation of the cytoplasmic tyrosine kinase domain, leading to activation of multiple signalling pathways, such as the PI3K/AKT and c-Jun $\mathrm{N}$-terminal kinase/STAT pathways ${ }^{23}$ (fig 1). The constitutive activation of KIT is one of the earliest transforming events in GISTs and occurs mainly through activating mutations in the kit gene, ${ }^{2814182124-28}$ but there is evidence of alternate activating mechanisms in a subset of tumours. Activating mutations of kit gene in GIST occur in exons 11, 9, 13 and 17 (fig 1), corresponding to the juxtamembrane intracellular regulatory domain, the extramembrane domain and the two intracytoplasmic tyrosine kinase domains, respectively. ${ }^{18} 290$ In the first phase, the presence of activating mutations seemed to be related to a malignant behaviour. ${ }^{31}{ }^{32}$ Subsequently, it was shown that most GISTs, even the tumours $<\mathrm{lcm}$ in size that were found incidentally, do harbour KIT mutations..$^{243-35}$ The meaning of KIT activation is highlighted by the recent introduction

Abbreviations: GIST, gastrointestinal stromal tumours; ICC, interstitial cells of Cajal; PDGFR, Platelet-derived growth factor receptor; PI3K, phosphatidylinositol-3kinase; RTK, receptor tyrosine kinases 
Table 1 Risk assessment categories of gastrointestinal stromal tumours based on size and mitotic index

\begin{tabular}{lll}
\hline Risk category & Size $(\mathrm{cm})$ & Mitoses $(H P F)$ \\
\hline Very low risk & $<2$ & $\leqslant 5 / 50$ \\
Low risk & $2-5$ & $\leqslant 5 / 50$ \\
Intermediate risk & $\leqslant 5$ & $5-10 / 50$ \\
& $5-10$ & $\leqslant 5 / 50$ \\
High risk & $>5$ & $>5 / 50$ \\
& $>10$ & Any mitotic rate \\
& Any size & $>10 / 50$ \\
\hline
\end{tabular}

HPF, high power field.

Data from Fletcher et al. ${ }^{5}$

of an inhibitor of RTKs, STI-571 (Imatinib, Gleevec, Novartis, Switzerland), which can induce regression of GISTs. Even advanced disease has been stabilised, with a return of quality of life. $^{36-42}$ The proper application of STI-571 is currently being investigated to identify the patients most likely to benefit from the treatment. So far, it is indicated for the treatment of metastatic inoperable disease or for cytoreduction in cases not amenable to macroscopically complete resection..$^{43}$ Many trials are in course which are, however, considering the possibility of using the drug in an adjuvant or neoadjuvant setting. ${ }^{44}$

Another member of the RTK family, PDGFR $\alpha$, is associated with the pathogenesis of GIST and mutations in $c$-kit are mutually exclusive with those in pdgfra. ${ }^{45}$ Interestingly, these two genes are located in the same chromosomal region (4q12). ${ }^{4647}$ The most frequent mutations in pdgfra are observed in exons 18 (second tyrosine kinase domain), 12 (regulatory juxtamembrane domain) or 14 (tyrosine kinase domain) (fig. 1). Both in vitro ${ }^{48}$ and in vivo ${ }^{49}$ studies have shown that the type of mutation in c-kit or pgdfra genes may predict the response to treatment with imatinib. It is now well known that a mutation in exon 11 of kit is associated with a better response to treatment with inhibitors of RTK, with a decreasing response for mutation in exons 9, 13, 17 and wild-type tumours. Depending on the mutation, some cells expressing the PDGFR $\alpha$ exon 18 mutant were sensitive to imatinib, whereas others were resistant. Mutants in exons 14 and 12 are sensitive to the drug.${ }^{14} 4950$ Moreover, tumours with mutations in the pdgfra gene are prevalently epithelioid. ${ }^{51}$ Some specific RTK mutations are also correlated with clinicopathological parameters, such as histological type, overall survival, localisation and risk classification. ${ }^{48} 495253$ Table 3 shows a brief summary of this correlation.

\section{MUTATIONS OF THE KIT GENE}

\section{Exon 11 (juxtamembrane domain)}

The juxtamembrane region of KIT inhibits receptor dimerisation in the absence of stem cell factor. Small in-frame deletions and insertions or point mutations on this domain affect this function. ${ }^{54} 55$ The reported frequency of mutations in exon 11 varies from $20 \%$ to $92 \%$, depending on the type of material (frozen or formalin fixed) and the technique used. $^{8141831-33515657}$ Most of the mutations are located between codons 556 and 560, with deletions and insertions prevalently affecting codons 557-559 and point mutations affecting codons 559 and $560 .^{824} 4951-533^{58-60}$ Internal tandem duplications are prevalently found towards the end of the exon (codons 576-580)..$^{52}$ The type of mutation is apparently related to the prognosis, with deletions behaving more aggressively in comparison with insertions and point mutations, ${ }^{8} 18295861-63$ and to the risk classification.

\section{Exon 9 (extracellular domain)}

The frequency of this mutation is described in $5-18 \%$ of cases, depending on the series. ${ }^{182428495364-72}$ It occurs mainly at codons 501-502 and is represented by duplication-insertion.
Table 2 Risk assessment categories of gastrointestinal stromal tumours based on size, mitotic index and anatomical location

\begin{tabular}{|c|c|c|c|}
\hline Group & Size $(\mathrm{cm})$ & $\begin{array}{l}\text { Mitoses } \\
\text { (HPF) }\end{array}$ & Risk category \\
\hline 1 & $\leqslant 2$ & $\leqslant 5 / 50$ & $\begin{array}{l}\text { Stomach: benign } \\
\text { Small intestine: benign }\end{array}$ \\
\hline 2 & $2-5$ & $\leqslant 5 / 50$ & $\begin{array}{l}\text { Stomach: very low malignant } \\
\text { potential } \\
\text { Small intestine: low malignant } \\
\text { potential }\end{array}$ \\
\hline $3 a$ & $5-10$ & $\leqslant 5 / 50$ & $\begin{array}{l}\text { Stomach: very low malignant } \\
\text { potential }\end{array}$ \\
\hline $3 b$ & $>10$ & $\leqslant 5 / 50$ & $\begin{array}{l}\text { Stomach: low-moderate malignant } \\
\text { potential } \\
\text { Small intestine: malignant potential }\end{array}$ \\
\hline 4 & $\leqslant 2$ & $>5 / 50$ & $\begin{array}{l}\text { Stomach: uncertain } \\
\text { Small intestine: malignant potential }\end{array}$ \\
\hline 5 & $2-5$ & $>5 / 50$ & $\begin{array}{l}\text { Stomach: low-moderate malignant } \\
\text { potential } \\
\text { Small intestine: malignant potential }\end{array}$ \\
\hline $\begin{array}{l}6 a \\
6 b\end{array}$ & $\begin{array}{l}>5 \\
>10\end{array}$ & $\begin{array}{l}>5 / 50 \\
>5 / 50\end{array}$ & $\begin{array}{l}\text { Stomach: malignant potential } \\
\text { Small intestine: malignant potential }\end{array}$ \\
\hline
\end{tabular}

HPF, high power field.

Data from Miettinen et al. ${ }^{78}$

Benign: no tumour-related mortality detected; very low malignant potential: $<3 \%$ progressive disease; uncertain: insufficient data; lowmoderate malignant potential: 12-15\% tumour-related mortality; malignant potential: $49-86 \%$ tumour-related mortality. ${ }^{78}$

It is associated with small intestinal localization and aggressive behaviour. ${ }^{18} 24$ Its mechanism probably affects an antidimerisation motif in the extracellular domain.

\section{Exon 13 (kinase I domain)}

This rare mutation, affecting codon 642 , occurs in $0.8-4.1 \%$ of

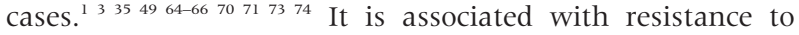
treatment with imatinib.

\section{Exon 17 (activation loop)}

The activating mechanism of these rare mutations $(0.6 \%$ of cases $)^{1833}$ affecting codons 820 and 822 , is unclear. A mutation occuring at codon 817, highly activating and frequently observed in other tumours (mastocytosis, acute myelogenous leukaemia), was never observed in GISTs, implying that the transforming mechanisms in the genesis of GIST are different from those of other tumours. ${ }^{18}{ }^{23}$

\section{MUTATION IN THE PDGFRA GENE}

They are observed in 7-12\% of cases, ${ }^{18} 202945495051$ occurring more often in exon 18 (activation loop) and rarely in exons 12 (juxtamembrane domain) and 14 (kinase I domain). pdgfra Mutants are prevalently epithelioid, located in the stomach and show weak or no immunohistochemical reactivity for KIT, $1820294549-517576$ but are functionally similar to kit mutants. The mutations occur in homologous domains, and activation of the downstream signalling pathways seem to be largely similar in the two mutant subtypes. ${ }^{77}$ Some degree of difference in gene expression may exist, but these data need confirmation in larger series. ${ }^{78}$

\section{Exon 18 (activation loop)}

Mutations occur at codons 842-849. Some of them (D842V, RD841-842KI and DI842-843IM) have shown considerable resistance to treatment with imatinib. ${ }^{45} 484979$

Exon 12 (juxtamembrane domain)

Mutations occur at codons 561-571 and are associated with good response to imatinib. ${ }^{18} 48-50$ 


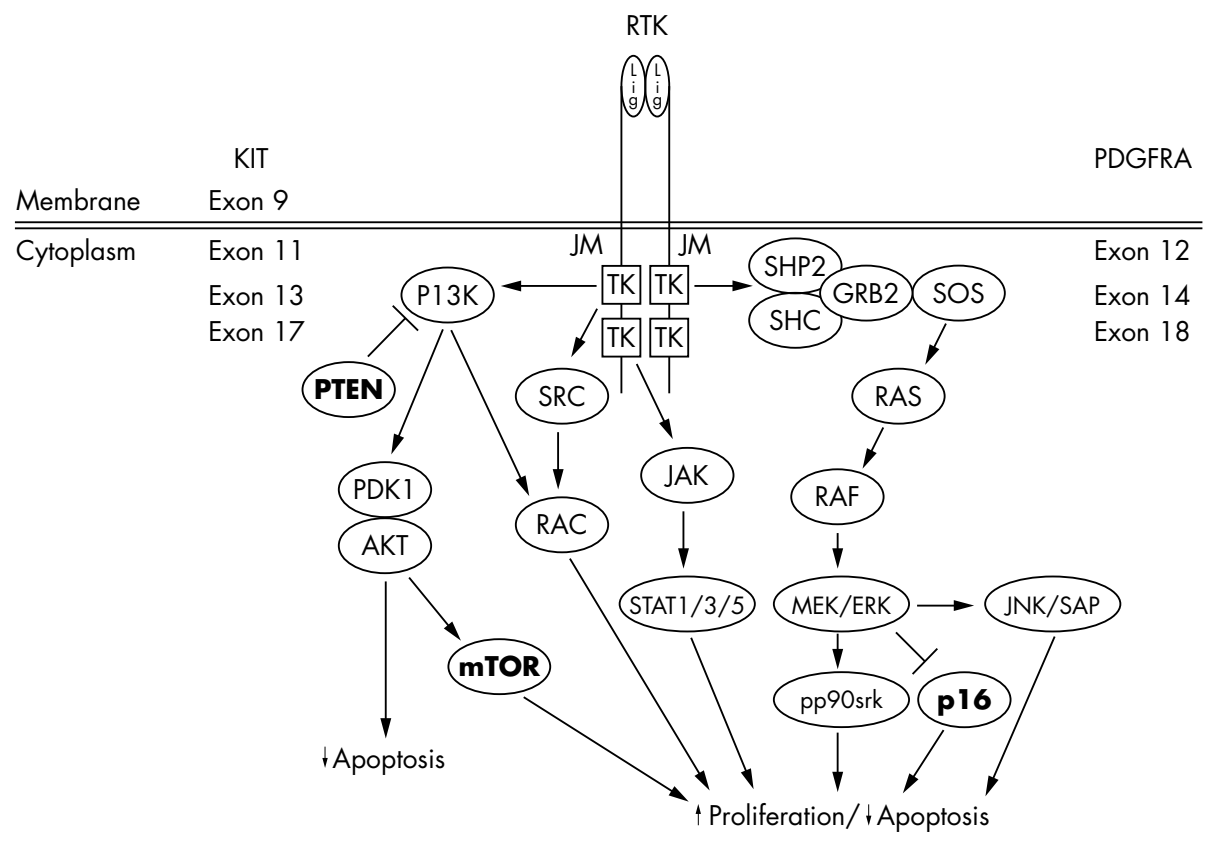

Figure 1 A simplified scheme of the signal transduction pathways activated by KIT or platelet-derived growth factor receptor $\alpha(P D G F R \alpha)$ (PI3K/AKT, Ras/mitogen activated protein kinase, JAK/STAT, sarcoma inducing gene with indication of the sites of activating mutations described in gastrointestinal stromal tumours. Actual and future drug targets are shown in bold. RTK, receptor tyrosine kinase; Lig, ligand; JM, juxtamembrane regulatory domain; TK, tyrosine kinase domain.

\section{Exon 14 (kinase I domain)}

A single rare mutation is described (N659K). It showed in vitro sensitivity to imatinib that is comparable to that observed in kit exon 13 mutants. ${ }^{20} 50$

\section{GISTS IN THE PAEDIATRIC AGE GROUP}

Most GISTs $(95 \%)$ arise in adults over 40 years of age. ${ }^{80} 81$ Some GISTs in children (6-14 years) and young adults (15-24 years) occur in connection with Carney's triad or neurofibromatosis type $1 .^{82-84}$ Rare cases of familial GISTs are described, which carry a kit or pdgfra germline mutation. ${ }^{57} 85-93$

\section{Sporadic paediatric GISTs}

Two series of paediatric GISTs ${ }^{6}{ }^{72}$ showed that these tumours occur without mutations in both kit and pdgfra. They show mainly an indolent course, with treatable recurrence. A specific gene expression signature was found in five cases, including overexpression of phosphate kinase alpha 1 (PHKAl), previously reported in a subset of acute myelogenous leukaemia in elderly women. ${ }^{72}$

\section{Paediatric GISTs associated with syndromes}

GISTs associated with neurofibromatosis type 1 do not have mutations in the kit or pdgfra gene, except in rare cases, not corresponding to the hot spots of sporadic GISTs. ${ }^{82}{ }^{94-96}$ They show an indolent course, preferential location in the small bowel and the colon and a tendency for multiple tumours. ${ }^{82}$ 94-96

Carney's triad ${ }^{97}$ is an association of GIST, paraganglioma and pulmonary chordoma. The genetic basis is unknown. In

Table 3 Summary of most frequent kit and pdgfra mutations in sporadic gastrointestinal stromal tumours

\begin{tabular}{|c|c|c|c|c|}
\hline Gene & Exon & Frequency (\%) & Mutation & Remarks \\
\hline \multirow[t]{4}{*}{ kit } & 11 & $20-60$ & $\begin{array}{l}\text { Deletion-insertion } 550-561 \\
\text { Point mutations } 557,559 \text {, } \\
560,576 \\
\text { Internal tandem duplications } \\
\text { beyond } 570 \text { ( } 3^{\prime} \text { end) }\end{array}$ & $\begin{array}{l}\text { Deletion is often } \\
\text { associated with bad } \\
\text { prognosis. Good } \\
\text { response to imatinib }\end{array}$ \\
\hline & 9 & $10-15$ & Duplication-insertion 501-502 & $\begin{array}{l}\text { Malignant behaviour } \\
\text { Small intestine } \\
\text { Intermediate response } \\
\text { to imatinib }\end{array}$ \\
\hline & 13 & $<5$ & Point mutation 642 & $\begin{array}{l}\text { Bad response to } \\
\text { imatinib }\end{array}$ \\
\hline & 17 & Rare $(<1)$ & Point mutation 820 & $\begin{array}{l}\text { Bad response to } \\
\text { imatinib }\end{array}$ \\
\hline \multirow[t]{3}{*}{ pdgfra } & 12 & Roughly 1 & $\begin{array}{l}\text { Point mutation } 561 \\
\text { Deletion-insertion } 560-571 \\
\text { Insertion } 582-586\end{array}$ & $\begin{array}{l}\text { Good response to } \\
\text { imatinib }\end{array}$ \\
\hline & 14 & $<0.5$ & Point mutation 659 & \\
\hline & 18 & $2-3$ & $\begin{array}{l}\text { Point mutation } 842 \\
\text { Deletion-substitution } 842-847\end{array}$ & $\begin{array}{l}\text { Mutation } 842(\mathrm{D} 842 \mathrm{~V}) \\
\text { resistant to imatinib } \\
\text { Other sensitive }\end{array}$ \\
\hline
\end{tabular}


all, $85 \%$ of patients are women. The diagnosis is generally made at a young age or in infancy. GISTs associated with Carney's triad do not harbour mutations in the kit or pdgfra genes. $^{1898}$

Familial GISTs are rare..$^{57}$ 85-93 Most affected families carry a kit germline mutation, inherited as autosomal dominant. One family showed a mutation is the pdgfra gene. Tumours are usually multiple and multifocal and arise at earlier ages than sporadic GISTs. They are associated with urticaria pigmentosa, melanocytic nevi, melanomas, achalasia or neuronal hyperplasia of the myenteric plexus..$^{55-93}$ Genetic mechanisms of progression are similar in familial and sporadic GISTs in adults. ${ }^{93}$

\section{Cytogenetic changes in GISTs}

The cytogenetic changes in GISTs were extensively studied by using different techniques (table 4). ${ }^{99-108}$

A correlation between the number and type of chromosomal changes and biological behaviour of GISTs was suggested. ${ }^{21}$ Karyotypes from about $60 \%$ of GISTs show a partial or total loss of chromosome $14 .^{21}{ }^{45}{ }^{104}{ }^{109}$ In particular, 14q11.1-12 and 14q22-24 are frequently deleted and can therefore represent sites for tumour suppressor genes participating early in the genesis of GISTs. ${ }^{104}{ }^{110}$ Loss of $22 \mathrm{q}$ is observed in about half of GISTs, with a higher frequency in advanced tumours. ${ }^{71}{ }^{111}$ It is possible therefore that an unknown gene on 22q may be responsible in the early stages of tumorigenesis and in tumour progression. ${ }^{1845111}$ Intermediate-risk and high-risk GISTs show loss of chromosomes 1p, 9p, 9q, 11 p p00102 104106108111 and gains of 8q and 17q. ${ }^{100} 102{ }^{105}{ }^{108}$ A sort of molecular pathway in the acquisition of genetic aberrations may parallel the progressive acquisition of malignancy. ${ }^{18}$ The precise role of single changes and their prognostic impact was not elucidated. Probably, cytogenetic changes in GISTs, above all in those with intermediate- and high-risk, are more complex..$^{35} 536177112113$ For instance, 8q gains were described in as many as $57 \%$ of metastatic GISTs. ${ }^{100}$ Gains of $c-m y c$, a well-known oncogene located on 8q24.12-13, in only 3 of 100 GISTs, ${ }^{61}$ implies that the target of this amplification are other, still unknown, oncogenes.

\section{Cell cycle network and GIST}

One possible target on chromosome $9 \mathrm{p}$ is the cyclindependent kinase inhibitor $2 \mathrm{~A}(c d k n 2 a)$ gene, located on 9p21, with its two transcripts, pl6INK4a and pl4ARF, which results from an alternative reading frame on the first exon. ${ }^{114}$ $c d k n 2 a$ has a central role in the control of cell cycle and apoptosis. pl4ARF inhibits mouse double minute 2 (MDM2) from degrading p53. ${ }^{115}$ pl6INK4A binds to the cyclindependent kinase 4 and blocks the phosphorylation of RBl protein, with consequent binding of the RBI to E2F1, which may influence the expression of thousand genes responsible for the control of proliferation, transcription and apoptosis. ${ }^{116-118}$ Inactivation of pl6INK4 may occur through mutation or promoter hypermethylation. ${ }^{16}{ }^{117}$ Molecular genetics and immunohistochemistry showed ${ }^{113} 119120$ that a loss of pl6 may have an independent value in identifying a subset of tumours with adverse prognosis. These results are supported by the observation that dysregulation of other members of the CDKN2a network may be linked to adverse prognosis. ${ }^{116}$ $\mathrm{We}^{61}$ analysed a series of 100 GISTs by fluorescent in situ hybridisation (FISH) and found amplifications of CyclinDl (ccndl) and $m d m 2$ genes in a subset of high-risk tumours. Mouse double minute 2 interacts with Raf/methyl-ethyl ketone /mitogen activated protein kinase ${ }^{121}$ and phosphatidylinositol-3-kinase/AKT/C-Jun N-terminal kinase ${ }^{122} 123$ pathways, both of which are triggered by KIT-activation. ${ }^{18} 21124$ We also found three cases of coamplifications of $c c n d l$ and $m d m 2 .{ }^{61}{ }^{125}$ An immunohistochemical study attempted to relate the cell cycle machinery and prognosis in 80 GISTs. ${ }^{126}$ Cyclin A, cyclin B1, cdc2 and Ki-67 were associated with a high risk of malignant behaviour and short disease-free survival.

\section{EXPRESSION STUDIES}

The first study of gene expression in GISTs ${ }^{34}$ showed that the presence of kit mutations (at that time, the presence of $p d g f r a$ mutations was not known) could identify a homogeneous expression profile, distinguishing GISTs from other mesenchymal tumours. In particular, genes that probably participated in the pacemaker function of the ICC (ion channels, receptors, transduction molecules) had a highly discriminant value. One of these protein kinase $\operatorname{C} \theta(p r k c \theta)$ is constitutively activated in GISTs and could therefore be a therapeutic target

\section{Take-home messages}

- Specific receptor tyrosine kinases (RTK) mutation is correlated with response-to-therapy and other clinicopathological parameters.

- The prognostic impact of single cytogenetic alterations has not been elucidated.

- Factors different from RTK may regulate signalling in gastrointestinal stromal tumours.

- We need a new paradigm of classification that combines pathological criteria and molecular changes.

\begin{tabular}{|c|c|c|c|}
\hline Changes & Method & Number of cases & Reference \\
\hline $\begin{array}{l}-1 p,-8 p,-9,-10 p,-10 q,-13, \\
-14 q,-22 q\end{array}$ & FISH & 14 & Kim, $2000^{99}$ \\
\hline$-14 q,-22 q$ & FISH & 12 & Breiner et al ${ }^{106}$ \\
\hline $\begin{array}{l}-1 p,-9 p,-14 q,-22 q,+5 p,+8 q, \\
+17 q,+20 q\end{array}$ & $\mathrm{CGH}$ & 95 & El-Rifai ef al ${ }^{100}$ \\
\hline $\begin{array}{l}-1,-7,-9,-13 q 14(\mathrm{Rb}),-14 q \\
-15,-22 q,+3,+4,+8,+10\end{array}$ & FISH & 22 & Debiec-Rychter et al ${ }^{104}$ \\
\hline $\begin{array}{l}-1 p,-13 q,-14,-15,-22,+1 q,+5, \\
+17 q,+20 p\end{array}$ & FISH & 14 & Derré et al ${ }^{105}$ \\
\hline$-1 p,-14,-21,-22,+7$ & $\begin{array}{l}\text { Cytogenetics, spectral } \\
\text { caryotyping }\end{array}$ & 10 & Andersson et al ${ }^{35}$ \\
\hline $\begin{array}{l}-1 p,-9 p,-10 q,-13 q,-14,-15 \\
-22,+5\end{array}$ & Cytogenetics & 19 & Gunawan, $2002^{107}$ \\
\hline $\begin{array}{l}-1 p,-9 q,-14 q,-15 q,-22 q,+4 q, \\
+5,+8 q\end{array}$ & $\mathrm{CGH}$ & 52 & Gunawan et al ${ }^{108}$ \\
\hline
\end{tabular}

$\mathrm{CGH}$, comparative genomic hybridisation; FISH, fluorescent in situ hybridisation. 
such as KIT. ${ }^{127}$ Another marker that has been identified by gene expression analysis is DOG-1, and it has been proposed also as a possible diagnostic marker. ${ }^{128}$ Subsequently gene expression in GISTs may differ according to the presence of mutation in kit or pdgfra, ${ }^{77}$ to the type of mutations in kit or $p d g f r a^{78}{ }^{129}$ or to the anatomical location of the tumour. ${ }^{129}$ Differentially expressed genes included ezrin, $p 70 S 6 k$, map $2 k 1$, akt, stat3, all of which were in the activating pathways downstream of kit or pdgfra. Koon et al ${ }^{130}$ described by realtime RT-PCR an association between the expression of cell cycle proteins (cyclinB1, centromere protein-F kinetochore protein) and tyrosine kinases with the biological behaviour in a small series of GISTs.

\section{SIGNALLING PATHWAYS}

KIT and PDGFR $\alpha$ in GISTs show a homogeneous transduction pathway consisting of mitogen-activate protein kinase, AKT, p70, STAT1, STAT3, PI3K, mammalian target of rapamydin and RAS..$^{18} 2145$ In particular, oncogenic signalling in these tumours differs from haematological diseases, and selective inhibition of the PI3K/mammalian target of rapamydin pathways reduces proliferation and inhibits apoptosis. $^{25}{ }^{26}$ The degree of activation differs from tumour to tumour, thus suggesting that factors different from KIT may regulate signalling in these neoplasias. ${ }^{26}$ The development of new targeted molecular treatments is aimed at selectively blocking these pathways.

\section{MOLECULAR CHANGES AND RESISTANCE TO IMATINIB}

Many patients with advanced GISTs develop resistance after variable degrees of initial response to treatment. ${ }^{131}$ Two kinds of resistance should be distinguished: ${ }^{44}$ (a) primary resistance: evidence of progression within the first 6 months of imatinib treatment, frequently associated with a wild-type KIT protein, mutation in exon 9 of kit or a D842V mutation in pdgfra; (b) secondary resistance: progression of disease after 6 months of treatment. The mechanisms of secondary resistance are heterogeneous: (a) acquisition of a secondary mutation in the kit or pdgfra genes; ${ }^{69}{ }^{132-135}$ (b) genomic amplification of kit and overexpression of the protein; ${ }^{133}$ and (c) activation of other RTKs. ${ }^{18}$ A new generation of tyrosine kinase inhibitors are presently under evaluation to solve this problem. ${ }^{132} 136$

\section{CONCLUSIONS}

GISTs probably do not constitute a single group of tumours; their biological behaviour (the prognosis and above all the response to treatment) depends both on classic clinicopathological parameters (ie, location, size, mitotic activity) and on the molecular changes that are detected in a given tumour (type of mutation in RTK, chromosomal alterations, expression of cell cycle proteins, activation and control of pathways downstream of the RTK, amplification or loss of genes, etc). Moreover, a relationship was found between some pathological characteristics and molecular alterations (for instance, tumours of the small intestine are associated with epithelioid morphology and mutation in exon 9 of kit). This underlines the need for a new paradigm of classification that can combine the old pathological criteria with the molecular changes.$^{18}$ In the era of targeted treatments (imatinib is one of the most successful examples), we are forced to change our point of view from the microscopic to the molecular level and to integrate all the data in a coherent schema.

\section{Authors' affiliations}

L Tornillo, L M Terracciano, Institute of Pathology, University of Basel, Basel, Switzerland
Competing interests: LT received a fee from Novartis for speaking. LT participated in 2004-5 in a study on gastrointestinal stromal tumours, which was funded by Novartis.

\section{REFERENCES}

1 Nilsson B, Bumming P, Meis-Kindblom JM, et al. Gastrointestinal stromal tumors: the incidence, prevalence, clinical course, and prognostication in the preimatinib mesylate era-a population-based study in western Sweden. Cancer 2005:103:821-9.

2 Kindblom LG, Remotti HE, Aldenborg F, et al. Gastrointestinal pacemaker cell tumor (GIPACT): gastrointestinal stromal tumors show phenotypic characteristics of the interstitial cells of Cajal. Am J Pathol 1998; 152:1259-69.

3 Miettinen M, Lasota J. Gastrointestinal stromal tumors-definition, clinical histological, immunohistochemical, and molecular genetic features and differential diagnosis. Virchows Arch 2001;438:1-12.

4 Miettinen M, El-Rifai W, Sobin HL, et al. Evaluation of malignancy and prognosis of gastrointestinal stromal tumors: a review. Hum Pathol 2002;33:478-83

5 Fletcher CD, Berman JJ, Corless C, et al. Diagnosis of gastrointestinal stromal tumors: a consensus approach. Hum Pathol 2002;33:459-65.

6 Miettinen M, Lasota J, Sobin LH. Gastrointestinal stromal tumors of the stomach in children and young adults: a clinicopathologic, immunohistochemical, and molecular genetic study of 44 cases with longterm follow-up and review of the literature. Am J Surg Pathol 2005;29:1373-81.

7 Miettinen M, Kopczynski J, Makhlouf HR, et al. Gastrointestinal stromal tumors, intramural leiomyomas, and leiomyosarcomas in the duodenum: a clinicopathologic, immunohistochemical, and molecular genetic study of 167 cases. Am J Surg Pathol 2003;27:625-41.

8 Miettinen M, Sobin LH, Lasota J. Gastrointestinal stromal tumors of the stomach: a clinicopathologic, immunohistochemical, and molecular genetic study of 1765 cases with long-term follow-up. Am J Surg Pathol 2005;29:52-68.

9 Mazur MT, Clark HB. Gastric stromal tumors. Reappraisal of histogenesis. Am J Surg Pathol 1983;7:507-19.

10 Lauwers GY, Erlandson RA, Casper ES, et al. Gastrointestinal autonomic nerve tumors. A clinicopathological, immunohistochemical, and ultrastructural study of 12 cases. Am J Surg Pathol 1993;17:887-97.

11 Suster S. Gastrointestinal stromal tumors. Semin Diagn Pathol 1996;13:297-313.

12 Huizinga JD, Thuneberg $L$, Kluppel $M$, et al. W/kit gene required for interstitial cells of Cajal and for intestinal pacemaker activity. Nature 1995:373:347-9.

13 Sircar K, Hewlett BR, Huizinga JD, et al. Interstitial cells of Cajal as precursors of gastrointestinal stromal tumors. Am J Surg Pathol 1999;23:377-89.

14 Hirota S, Isozaki K, Moriyama Y, et al. Gain-of-function mutations of c-kit in human gastrointestinal stromal tumors. Science 1998;279:577-80.

15 Fletcher CD, Fletcher JA. Testing for KIT (CD1 17) in gastrointestinal stromal tumors: another Herceptest? Appl Immunohistochem Mol Morphol 2002; 10:197-8.

16 Miettinen M, Majidi M, Lasota J. Pathology and diagnostic criteria of gastrointestinal stromal tumors (GISTs): a review. Eur J Cancer 2002;38(Suppl 5):S39-51.

17 Adachi Y, Yamamoto H, Nosho K, et al. Gigantic gastrointestinal stromal tumor in the pelvis. Int $J$ Colorectal Dis, 2005;20, 196-8.

18 Corless CL, Fletcher JA, Heinrich MC. Biology of gastrointestinal stromal tumors. J Clin Oncol 2004;22:3813-25.

19 Debiec-Rychter M, Wasag B, Stul M, et al. Gastrointestinal stromal tumours (GISTs) negative for KIT (CD1 17 antigen) immunoreactivity. J Pathol 2004; 202:430-8

20 Medeiros F, Corless CL, Duensing A, et al. KIT-negative gastrointestinal stromal tumors: proof of concept and therapeutic implications. Am J Surg Pathol 2004;28:889-94.

21 Heinrich MC, Rubin BP, Longley BJ, et al. Biology and genetic aspects of gastrointestinal stromal tumors: KIT activation and cytogenetic alterations. Hum Pathol 2002;33:484-95.

22 Ashman LK. The biology of stem cell factor and its receptor C-kit. Int J Biochem Cell Biol 1999;31:1037-51.

23 Longley BJ, Reguera MJ, Ma Y. Classes of c-KIT activating mutations: proposed mechanisms of action and implications for disease classification and therapy. Leuk Res 2001;25:571-6.

24 Corless CL, McGreevey L, Haley A, et al. KIT mutations are common in incidental gastrointestinal stromal tumors one centimeter or less in size. Am J Pathol 2002;160:1567-72.

25 Duensing A, Heinrich MC, Fletcher CD, et al. Biology of gastrointestinal stromal tumors: KIT mutations and beyond. Cancer lnvest 2004;22:106-16.

26 Duensing A, Medeiros F, McConarty B, et al. Mechanisms of oncogenic KIT signal transduction in primary gastrointestinal stromal tumors (GISTs). Oncogene 2004;23:3999-4006.

27 Hirota S, Isozaki K, Nishida T, et al. Effects of loss-of-function and gain-offunction mutations of c-kit on the gastrointestinal tract. J Gastroenterol 2000;35(Suppl 12):75-9.

28 Hirota S, Nishida T, Isozaki K, et al. Gain-of-function mutation at the extracellular domain of KIT in gastrointestinal stromal tumours. J Pathol 2001;193:505-10.

29 Corless CL. Assessing the prognosis of gastrointestinal stromal tumors: a growing role for molecular testing. Am J Clin Pathol 2004;122:11-3. 
30 Sihto $\mathrm{H}$, Sarlomo-Rikala M, Tynninen O, et al. KIT and platelet-derived growth factor receptor alpha tyrosine kinase gene mutations and KIT amplifications in human solid tumors. J Clin Oncol 2005:23:49-57.

31 Lasota J, Jasinski M, Sarlomo-Rikala M, et al. Mutations in exon 11 of c-Kit occur preferentially in malignant versus benign gastrointestinal stromal tumors and do not occur in leiomyomas or leiomyosarcomas. Am J Pathol 1999; 154:53-60.

32 Taniguchi $\mathrm{M}$, Nishida T, Hirota $\mathrm{S}$, et al. Effect of c-kit mutation on prognosis of gastrointestinal stromal tumors. Cancer Res 1999:59:4297-300.

33 Rubin BP, Singer S, Tsao C, et al. KIT activation is a ubiquitous feature of gastrointestinal stromal tumors. Cancer Res 2001;61:81 18-21.

34 Allander SV, Nupponen NN, Ringner M, et al. Gastrointestinal stromal tumors with KIT mutations exhibit a remarkably homogeneous gene expression profile. Cancer Res 2001;61:8624-8.

35 Andersson J, Sjogren H, Meis-Kindblom JM, et al. The complexity of KIT gene mutations and chromosome rearrangements and their clinical correlation in gastrointestinal stromal (pacemaker cell) tumors. Am J Pathol 2002;160:15-22

36 Tuveson DA, Willis NA, Jacks T, et al. STI571 inactivation of the gastrointestinal stromal fumor c-KIT oncoprotein: biological and clinical implications. Oncogene 2001;20:5054-8.

37 Levitzki A. Tyrosine kinases as targets for cancer therapy. Eur J Cancer 2002;38(Suppl 5):S1 1-8

38 Joensuv $\mathrm{H}$. Treatment of inoperable gastrointestinal stromal tumor (GIST) with imatinib (Glivec, Gleevec). Med Klin 2002;97(Suppl 1):28-30.

39 Joensuu H, Roberts PJ, Sarlomo-Rikala M, et al. Effect of the tyrosine kinase inhibitor STI571 in a patient with a metastatic gastrointestinal stromal tumor. N Engl J Med 2001;344:1052-6.

40 Demetri GD. Targeting c-kit mutations in solid tumors: scientific rationale and novel therapeutic options. Semin Oncol 2001;28(5 Suppl 17):19-26.

41 Demetri GD. Targeting the molecular pathophysiology of gastrointestinal stromal tumors with imatinib. Mechanisms, successes, and challenges to rational drug development. Hematol Oncol Clin North Am 2002;16:1115-24.

42 Demetri GD, von Mehren M, Blanke CD, et al. Efficacy and safety of imatinib mesylate in advanced gastrointestinal stromal tumors. N EnglJ Med 2002;347:472-80.

43 Dagher R, Cohen $M$, Williams $G$, et al. Approval summary: imatinib mesylate in the treatment of metastatic and/or unresectable malignant gastrointestinal stromal tumors. Clin Cancer Res 2002;8:3034-8.

44 Blay JY, Bonvalot S, Casali P, et al. Consensus meeting for the management of gastrointestinal stromal tumors. Report of the GIST Consensus Conference of 20-21 March 2004, under the auspices of ESMO. Ann Oncol 2005; 16:566-78

45 Heinrich MC, Corless CL, Duensing A, et al. PDGFRA activating mutations in gastrointestinal stromal tumors. Science 2003;299:708-10.

46 Hsieh CL, Navankasattusas S, Escobedo JA, et al. Chromosomal localization of the gene for AA-type platelet-derived growth factor receptor (PDGFRA) in humans and mice. Cytogenet Cell Genet 1991;56:160-3.

47 d'Auriol L, Mattei MG, Andre C, et al. Localization of the human c-kit protooncogene on the q1 l-q12 region of chromosome 4. Hum Genet 1988:78:374-6.

48 Hirota S, Ohashi A, Nishida T, et al. Gain-of-function mutations of plateletderived growth factor receptor alpha gene in gastrointestinal stromal tumors. Gastroenterology 2003;125:660-7.

49 Heinrich MC, Corless CL, Demetri GD, et al. Kinase mutations and imatinib response in patients with metastatic gastrointestinal stromal tumor. J Clin Oncol 2003;21:4342-9

50 Corless CL, Schroeder A, Griffith D, et al. PDGFRA mutations in gastrointestinal stromal tumors: frequency, spectrum and in vitro sensitivity to imatinib. J Clin Oncol 2005:23:5357-64.

51 Lasota J, Dansonka-Mieszkowska A, Sobin LH, et al. A great majority of GISTs with PDGFRA mutations represent gastric tumors of low or no malignant potential. Lab Invest 2004;84:874-83.

52 Lasota J, Dansonka-Mieszkowska A, Stachura T, et al. Gastrointestinal stromal tumors with internal tandem duplications in $3^{\prime}$ end of KIT juxtamembrane domain occur predominantly in stomach and generally seem to have a favorable course. Mod Pathol 2003;16:1257-64.

53 Lasota J, Kopczynski J, Sarlomo-Rikala M, et al. KIT 1530ins6 mutation defines a subset of predominantly malignant gastrointestinal stromal s of intestinal origin. Hum Pathol 2003;34:1306-12.

54 Chan PM, llangumaran S, La Rose J, et al. Autoinhibition of the kit receptor tyrosine kinase by the cytosolic juxtamembrane region. Mol Cell Biol 2003:23:3067-78.

55 Kitayama $\mathrm{H}$, Kanakura $\mathrm{Y}$, Furitsu $\mathrm{T}$, et al. Constitutively activating mutations of c-kit receptor tyrosine kinase confer factor-independent growth and tumorigenicity of factor-dependent hematopoietic cell lines. Blood 1995; 85:790-8

56 Ernst SI, Hubbs AE, Przygodzki RM, et al. KIT mutation portends poor prognosis in gastrointestinal stromal/smooth muscle tumors. Lab lnvest 1998;78:1633-6

57 Li SQ, O'Leary TJ, Sobin LH, et al. Analysis of KIT mutation and protein expression in fine needle aspirates of gastrointestinal stromal/smooth muscle tumors. Acta Cytol 2000;44:981-6.

58 Corless $\mathrm{CL}, \mathrm{McGreevey} \mathrm{L,} \mathrm{Town} \mathrm{A,} \mathrm{et} \mathrm{al.} \mathrm{KIT} \mathrm{gene} \mathrm{deletions} \mathrm{at} \mathrm{the} \mathrm{intron} \mathrm{10-}$ exon 11 boundary in Gl stromal tumors. J Mol Diagn 2004;6:366-70.

59 Miettinen $M$, Furlong $M$, Sarlomo-Rikala $M$, et al. Gastrointestinal stromal tumors, intramural leiomyomas, and leiomyosarcomas in the rectum and anus: a clinicopathologic, immunohistochemical, and molecular genetic study of 144 cases. Am J Surg Pathol 2001;25:1121-33.
60 Miettinen $M$, Sobin LH. Gastrointestinal stromal tumors in the appendix: a clinicopathologic and immunohistochemical study of four cases. Am J Surg Pathol 2001; 25: 1433-7.

61 Tornillo L, Duchini G, Carafa V et al. Patterns of gene amplification in gastrointestinal stromal tumors (GIST). Lab Invest 2005;85:921-31.

62 Wardelmann E, Losen I, Hans V, et al. Deletion of Trp- 557 and Lys-558 in the juxtamembrane domain of the c-kit protooncogene is associated with metastatic behavior of gastrointestinal stromal tumors. Int J Cancer 2003; 106:887-95.

63 Martin J, Poveda A, Llombart-Bosch A, et al. Deletions affecting codons 557558 of the c-KIT gene indicate a poor prognosis in patients with completely resected gastrointestinal stromal tumors: a study by the Spanish Group for Sarcoma Research (GEIS). J Clin Oncol 2005;23:6190-8.

64 Sakurai S, Oguni S, Hironaka M, et al. Mutations in c-kit gene exons 9 and 13 in gastrointestinal stromal tumors among Japanese. Jpn J Cancer Res 2001;92:494-8.

65 Lux ML, Rubin BP, Biase TL, et al. KIT extracellular and kinase domain mutations in gastrointestinal stromal tumors. Am J Pathol 2000;156:791-5. 66 Debiec-Rychter M, Dumez H, Judson I, et al. Use of c-KIT/PDGFRA mutational analysis to predict the clinical response to imatinib in patients with advanced gastrointestinal stromal tumours entered on phase I and II studies of the EORTC Soft Tissue and Bone Sarcoma Group. Eur J Cancer 2004;40:689-95

$67 \mathrm{Kim}$ TW, Lee H, Kang YK, et al. Prognostic significance of c-kit mutation in localized gastrointestinal stromal tumors. Clin Cancer Res 2004; 10:3076-81

68 Yamamoto H, Oda Y, Kawaguchi K, et al. c-kit and PDGFRA mutations in extragastrointestinal stromal tumor (gastrointestinal stromal tumor of the soff tissue). Am J Surg Pathol 2004;28:479-88.

69 Chen LL, Trent JC, Wu EF, et al. A missense mutation in KIT kinase domain 1 correlates with imatinib resistance in gastrointestinal stromal tumors. Cancer Res 2004:64:5913-9.

70 Willmore C, Holden JA, Zhou L, et al. Detection of c-kit-activating mutations in gastrointestinal stromal tumors by high-resolution amplicon melting analysis. Am J Clin Pathol 2004;122:206-16.

71 Antonescu CR, Sommer G, Sarran L, et al. Association of KIT exon 9 mutations with nongastric primary site and aggressive behavior: KIT mutation analysis and clinical correlates of 120 gastrointestinal stromal tumors. Clin Cancer Res 2003;9:3329-37.

72 Prakash S, Sarran L, Socci N, et al. Gastrointestinal stromal tumors in children and young adults: a clinicopathologic, molecular, and genomic study of 15 cases and review of the literature. J Pediatr Hematol Oncol 2005;27:179-87.

73 Kinoshita K, Isozaki K, Hirota S, et al. c-kit gene mutation at exon 17 or 13 is very rare in sporadic gastrointestinal stromal tumors. J Gastroenterol Hepatol 2003;18:147-51

74 Joensuu H, Kindblom LG. Gastrointestinal stromal tumors-a review. Acta Orthop Scand Suppl 2004;75:62-71.

75 Pauls K, Merkelbach-Bruse S, Thal D, et al. PDGFRalpha- and c-kit-mutated gastrointestinal stromal tumours (GISTs) are characterized by distinctive histological and immunohistochemical features. Histopathology 2005; 46:166-75.

76 Penzel R, Aulmann S, Moock M, et al. The location of KIT and PDGFRA gene mutations in gastrointestinal stromal tumours is site and phenotype associated. J Clin Pathol 2005;58:634-9.

77 Subramanian S, West RB, Corless CL, et al. Gastrointestinal stromal tumors (GISTs) with KIT and PDGFRA mutations have distinct gene expression profiles. Oncogene 2004;23:7780-90.

78 Kang HJ, Nam SW, Kim H, et al. Correlation of KIT and platelet-derived growth factor receptor alpha mutations with gene activation and expression profiles in gastrointestinal stromal tumors. Oncogene 2005;24:1066-74.

79 Ohashi A, Kinoshita K, Isozaki K, et al. Different inhibitory effect of imatinib on phosphorylation of mitogen-activated protein kinase and Akt and on proliferation in cells expressing different types of mutant platelet-derived growth factor receptor-alpha. Int J Cancer 2004;111:317-21.

80 DeMatteo RP, Lewis JJ, Leung $\mathrm{D}$, et al. Two hundred gastrointestinal stromal tumors: recurrence patterns and prognostic factors for survival. Ann Surg 2000;231:51-8

81 Tran T, Davila JA, El-Serag HB. The epidemiology of malignant gastrointestinal stromal tumors: an analysis of 1,458 cases from 1992 to 2000. Am J Gastroenterol 2005;100:162-8.

82 Andersson J, Sihto H, Meis-Kindblom JM, et al. NF1-associated gastrointestinal stromal tumors have unique clinical, phenotypic, and genotypic characteristics. Am J Surg Pathol 2005;29:1 170-6.

83 Carney JA, Stratakis CA. Familial paraganglioma and gastric stromal sarcoma: a new syndrome distinct from the Carney triad. Am J Med Genet 2002; 108:132-9.

84 Kinoshita K, Hirota S, Isozaki K, et al. Absence of c-kit gene mutations in gastrointestinal stromal tumours from neurofibromatosis type 1 patients. J Pathol 2004;202:80-5.

85 Beghini A, Tibiletti MG, Roversi G, et al. Germline mutation in the juxtamembrane domain of the kit gene in a family with gastrointestinal stromal tumors and urticaria pigmentosa. Cancer 2001;92:657-62.

86 Chen H, Hirota S, Isozaki K, et al. Polyclonal nature of diffuse proliferation of interstitial cells of Cajal in patients with familial and multiple gastrointestinal stromal tumours. Gut 2002:51:793-6.

87 Chompret $A$, Kannengiesser $C$, Barrois $M$, et al. PDGFRA germline mutation in a family with multiple cases of gastrointestinal stromal tumor. Gastroenterology 2004;126:318-21. 
88 Hirota S, Nishida T, Isozaki K, et al. Familial gastrointestinal stromal tumors associated with dysphagia and novel type germline mutation of KIT gene. Gastroenterology 2002;122:1493-9.

89 Hirota S, Okazaki T, Kitamura Y, et al. Cause of familial and multiple gastrointestinal autonomic nerve tumors with hyperplasia of interstitial cells of Cajal is germline mutation of the c-kit gene. Am J Surg Pathol 2000;24:326-7.

90 Maeyama $\mathrm{H}$, Hidaka $\mathrm{E}$, Ota $\mathrm{H}$, et al. Familial gastrointestinal stromal tumor with hyperpigmentation: association with a germline mutation of the c-kit gene. Gastroenterology 2001;120:210-5.

91 Nishida T, Hirota S, Taniguchi M, et al. Familial gastrointestinal stromal tumours with germline mutation of the KIT gene. Nat Genet 1998; 19:323-4.

92 Hartmann K, Wardelmann E, Ma Y, et al. Novel germline mutation of KIT associated with familial gastrointestinal stromal tumors and mastocytosis. Gastroenterology 2005;129:1042-6.

93 Li FP, Fletcher JA, Heinrich MC, et al. Familial gastrointestinal stromal tumor syndrome: phenotypic and molecular features in a kindred. $J$ Clin Oncol 2005;23:2735-43.

94 Cheng SP, Huang MJ, Yang TL, et al. Neurofibromatosis with gastrointestinal stromal tumors: insights into the association. Dig Dis Sci 2004;49:1 165-9.

95 Takazawa Y, Sakurai S, Sakuma Y, et al. Gastrointestinal stromal tumors of neurofibromatosis type I (von Recklinghausen's disease). Am J Surg Pathol 2005;29:755-63.

96 Yantiss RK, Rosenberg AE, Sarran L, et al. Multiple gastrointestinal stromal tumors in type I neurofibromatosis: a pathologic and molecular study. Mod Pathol 2005; 18:47-84.

97 Carney JA. Gastric stromal sarcoma, pulmonary chondroma, and extraadrenal paraganglioma (Carney triad): natural history, adrenocortical component, and possible familial occurrence. Mayo Clin Proc 1999;74:543-52.

98 Diment J, Tamborini E, Casali P, et al. Carney triad: case report and molecular analysis of gastric tumor. Hum Pathol 2005;36:112-6.

$99 \operatorname{Kim~NG}$, Kim JJ, Aha JY, et al. Putative chromsomal deletions on 9P, 9Q and $22 Q$ occur preferentially in maligrant gastrointestinal stromal tumors. Int $J$ Cancer 2000;85:633-8.

100 El-Rifai W, Sarlomo-Rikala M, Andersson LC, et al. DNA sequence copy number changes in gastrointestinal stromal tumors: tumor progression and prognostic significance. Cancer Res 2000;60:3899-03.

101 Sarlomo-Rikala M, El-Rifai W, Lahtinen T, et al. Different patterns of DNA copy number changes in gastrointestinal stromal tumors, leiomyomas, and schwannomas. Hum Pathol 1998;29:476-81.

102 Debiec-Rychter M, Pauwels P, Lasota J, et al. Complex genetic alterations in gastrointestinal stromal tumors with autonomic nerve differentiation. Mod Pathol 2002; 15:692-8.

103 Debiec-Rychter M, Sciot R, Pauwels P, et al. Molecular cytogenetic definition of three distinct chromosome arm 14q deletion intervals in gastrointestinal stromal tumors. Genes Chromosomes Cancer 2001;32:26-32.

104 Debiec-Rychter M, Lasota J, Sarlomo-Rikala M, et al. Chromosomal aberrations in malignant gastrointestinal stromal tumors: correlation with cKIT gene mutation. Cancer Genet Cytogenet 2001;128:24-30.

105 Derre J, Lagace R, Terrier $\mathrm{P}$, et al. Consistent DNA losses on the short arm of chromosome 1 in a series of malignant gastrointestinal stromal tumors. Cancer Genet Cytogenet 2001; 127:30-3.

106 Breiner JA, Meis-Kindblom J, Kindblom LG, et al. Loss of 14q and 22q in gastrointestinal stromal tumors (pacemaker cell tumors). Cancer Genet Cytogenet 2000;120:111-6.

107 Gunawan B, Bergmann F, Hoer J, et al. Biological and clinical significance of cytogenetic abnormalities in low-risk and high-risk gastrointestinal stromal tumours. Hum Pathol 2002;33:316-21.

108 Gurchan B, Schulten HJ, von Heydebreck A, et al. Site-independent prognostic value of chromosome $9 \mathrm{q}$ loss in primary gastrointestinal stromal tumours. J Pathol 2004;2002:421-9.

109 Fukasawa T, Chong JM, Sakurai S, et al. Allelic loss of 14q and 22q, NF2 mutation, and genetic instability occur independently of c-kit mutation in gastrointestinal stromal tumor. Jpn J Cancer Res 2000;91:1241-9.

110 El-Rifai W, Sarlomo-Rikala M, Andersson LC, et al. High-resolution deletion mapping of chromosome 14 in stromal tumors of the gastrointestinal tract suggests two distinct tumor suppressor loci. Genes Chromosomes Cancer 2000;27:387-91.

111 Lasota J, Wozniak A, Kopczynski J, et al. Loss of heterozygosity on chromosome $22 q$ in gastrointestinal stromal tumors (GISTs): a study on 50 cases. Lab lnvest 2005;85:237-47.
112 Lasota J, Wozniak A, Kopczynski J, et al. Loss of heterozygosity on chromosome $22 q$ in gastrointestinal stromal tumors (GISTs): a study on 50 cases. Lab Invest 2005;85:237-47.

113 Schneider-Stock R, Boltze C, Lasota J, et al. Loss of $\mathrm{p} 16$ protein defines highrisk patients with gastrointestinal stromal tumors: a tissue microarray study. Clin Cancer Res 2005;11(2 Pt 1):638-45.

114 Quelle DE, Zindy F, Ashmun RA, et al. Alternative reading frames of the INK4a tumor suppressor gene encode two unrelated proteins capable of inducing cell cycle arrest. Cell 1995;83:993-1000.

115 Pomerantz J, Schreiber-Agus N, Liegeois NJ, et al. The ink4a tumor supppressor gene product, p19Arf, interacts with MDM2 and neutralizes MDM2's inhibition of p53. Cell 1998:92:713-23.

116 Haller F, Gunawan B, von Heydebreck A, et al. Prognostic role of E2F1 and members of the CDKN2A network in gatrointestinal stromal tumors. Clin Cancer Res 2005; 11:6589-97.

117 Müller H, Bracken AP, Vernell R, et al. E2Fs regulate the expresion of genes involved in differentiation, development, proliferation and apoptosis. Genes Dev 2001; 15:267-85.

118 Serrano M, Hannon GJ, Beach D. A new regulatory motif in cell cycle control causing specific inhibition of cyclin/CDK4. Nature 1993;366:704-7.

119 Ricci R, Arena V, Castri F, et al. Role of p16/INK4a in gastrointestinal stromal tumor progression. Am J Clin Pathol 2004; 122:35-43.

120 Schneider-Stock R, Boltze C, Lasota J, et al. High prognostic value of pl6ink4 alterations in gastrointestinal stromal tumors. J Clin Oncol 2003;21:1688-97.

121 Ries S, Biederer C, Woods D, et al. Opposing effects of Ras on p53: transcriptional activation of $\mathrm{mdm} 2$ and induction of p19ARF. Cell 2000; 103:321-30.

122 Mayo LD, Donner DB. A phosphatidylinositol 3-kinase/Akt pathway promotes translocation of $\mathrm{Mdm} 2$ from the cytoplasm to the nucleus. Proc Natl Acad Sci USA 2001;98:11598-603.

123 Mayo LD, Donner DB. The PTEN, Mdm2, p53 tumor suppressor-oncoprotein network. Trends Biochem Sci 2002;27:462-7.

124 Linnekin D. Early signaling pathways activated by c-Kit in hematopoietic cells. Int J Biochem Cell Biol 1999:31:1053-74.

125 Xiao ZX, Chen J, Levine AJ, et al. Interaction between the retinoblastoma protein and the oncoprotein MDM2. Nature 1995;375:694-8.

126 Nakamura N, Yamamoto H, Yao T, et al. Prognostic significance of expressions of cell-cycle regulatory proteins in gastrointestinal stromal tumor and the relevance of the risk grade. Hum Pathol 2005;36:828-37.

127 Duensing A, Joseph NE, Medeiros F, et al. Protein kinase C theta (PKCtheta) expression and constitutive activation in gastrointestinal stromal fumors (GISTs). Cancer Res 2004;64:5127-31.

128 West RB, Corless CL, Chen X, et al. The novel marker, DOG1, is expressed ubiquitously in gastrointestinal stromal tumors irrespective of KIT or PDGFRA mutation status. Am J Pathol 2004;165:107-13.

129 Antonescu CR, Viale A, Sarran L, et al. Gene expression in gastrointestinal stromal tumors is distinguished by KIT genotype and anatomic site. Clin Cancer Res 2004; 10:3282-90.

130 Koon N, Zaika A, Moskaluk CA, et al. Clustering of molecular alterations in gastroesophageal carcinomas. Neoplasia 2004;6:143-9.

131 Verweii J, Casali PG, Zalcberg J, et al. Progression-free survival in gastrointestinal stromal tumours with high-dose imatinib: randomised trial. Lancet 2004;364:1127-34.

132 Antonescu CR, Besmer P, Guo T, et al. Acquired resistance to imatinib in gastrointestinal stromal fumor occurs through secondary gene mutation. Clin Cancer Res 2005;11:4182-90.

133 Debiec-Rychter M, Cools J, Dumez H, et al. Mechanisms of resistance to imatinib mesylate in gastrointestinal stromal tumors and activity of the PKC412 inhibitor against imatinib-resistant mutants. Gastroenterology 2005; 128:270-9.

134 Tamborini E, Bonadiman L, Greco A, et al. A new mutation in the KIT ATP pocket causes acquired resistance to imatinib in a gastrointestinal stromal tumor patient. Gastroenterology 2004;127:294-9.

135 Tamborini E, Gabanti E, Lagonigro MS, et al. KIT/Val654 Ala receptor detected in one imatinib-resistant GIST patient. Cancer Res 2005;65:1115; author reply 1115

136 Growney JD, Clark JJ, Adelsperger J, et al. Activation mutations of human CKIT resistant to imatinib mesylate are sensitive to the tyrosine kinase inhibitor PKC412. Blood 2005; 106:721-4. 